\title{
Transforming Higher educational institution administration through ICT
}

\author{
J. Meenakumari \\ Associate Professor, Christ University \\ Bangalore, India
}

\author{
Dr. R. Krishnaveni \\ Professor, PSG Institute of Management \\ Coimbatore, India
}

\begin{abstract}
The rapid development in Indian higher education sector has increased the focus on reforms in higher educational institution administration. Efficiency and accountability have become important elements, and the integration of Information and Communication Technology (ICT) into the educational administration process has become a necessity. The objective of this study is to know the current extent of ICT integration in Indian higher education institutions. The factors contributing to the successful integration of ICT into higher education administration (i.e., Knowledge administration and Information administration which constitute e-administration) are also discussed
\end{abstract}

Keywords-Higher education; Information and Communication Technology; Integration; Knowledge administration; Information administration; e-administration.

\section{INTRODUCTION}

\section{A. Overview}

Developing nations has seen a tremendous growth in higher education sector. India is a developing nation and it has been expanding in every field. Education saw an essential change gradually after Independence. Development of education in India brought about a transformation and the concept of education got modified. India has the third largest higher education system in the world, behind only the United States and China (Harsh V. Pant 2008). As on 31.12.2009, there are 504 Universities and University-level institutions including 40 Central Universities, 243 State Universities, 53 State Private Universities, 130 deemed Universities and 33 Institutes of national importance (Ministry of HRD, India).

\section{B. Indian Higher Education System}

The department of higher education is an imperative segment of the Ministry of Human Resource Development, India. The ministry is headed by the Minister of HRD. He is currently assisted by two Ministers of State. The Minister provides policy and overall leadership to the Ministry. At the executive level, the department of higher education is headed by a secretary, who is assisted by one additional secretary, and several joint secretaries or equivalent officers. Each joint secretary heads a bureau and at present, work of the department is divided into six bureaus. The higher education annual report of the year 2009-2010 revealed that 136.42 lakh students were enrolled in the institutions of Higher Education as against
123.77 lakhs in the previous year. This clearly shows that the higher education sector is expanding in all areas.

According to the World Bank Report (1994), higher education is of paramount importance for social and economic development of a nation. This rapid development and expansion in higher education sector has necessitated a good Information and Communication technology (ICT)-based administration system. ICT's role in higher education is solicited for improving quality, widening access and enhancing operational efficiency across all functions in higher education sector and to create new dynamics in higher education both at micro and macro levels. Hence, at present the integration of ICT into higher education has become inevitable.

\section{THEORETICAL BACKGROUND}

Change has been happening at an uneven pace in any growth-oriented industry, and the education sector is no exception. In the current age that we live in, technology has become an important component. A tremendous growth in the field of education has made governance in academic communication a very complex task. The 21 st century has witnessed rapid advancements in technology which has led to far-reaching developments in the administrative system. Costeffective technology combined with the flexibility in learning and administrative activities is essential to enhance efficiency. Computers can be used extensively for educational administration. The following are some of the areas where computers can be used for effective educational administration (Ben-Zion Barta et. al. 1995):

- General Administration

- Payroll and Financial Accounting

- Administration of Student Data

- Inventory Management

- Personnel Records Maintenance

- Library System

Rapidly growing computer technology embraced more centers of learning; procedures became necessary to respond to the influx of demands generated by faculty, students and administrators (Maynard J. Bratlien 1989). Information and Communication Technology plays a vital role in supporting powerful, efficient management and administration in the education sector. Technology can be used right from student 
administration to various resource administrations in an education institution (Christiana Maki 2008). The increasing student population in higher education accelerated the need for ICTs to process, store and retrieve data in a fast, systemic and accurate fashion. The focus of e-administration in higher education is on the creation of an efficient electronic administration by handling existing resources economically. It aims at adding value to the educational sector by simplification of a lot of diversified management and administrative tasks. According to Sanat Kaul (2006), the usage of ICT in higher education institutions starts from the early stages of receiving e-notifications regarding admission, course schedules, and billing procedures and continues till the end of the course including online publication of results. The Action Plan for reforms in the field of higher education revealed that "The potential of Information Communication Technology (ICT) should be fully utilized" (UNESCO 1998).

The main functional areas of e-administration namely, Knowledge administration and Information administration was identified based on the fact that both instructional and managerial are the two main perspectives of administrative tasks in any higher education institutions. Some studies have empirically considered only the knowledge administration that is activities relating to teaching-learning process and hence studies pertaining to Information administration were lacking. Consequently, the model was formed by linking both the functional areas so as to represent a whole model that could be implemented in higher education institutions.

The functional areas that contribute towards e-administration are discussed below along with the constructs that contribute to these functional areas. The study done by Diem Ho (2007) and many others revealed that Knowledge cycle consists of knowledge acquisition, assimilation and development, and evaluation. Based on research studies and literature reviews, it can be concluded that knowledge administration is a cyclic process comprising Knowledge acquisition / Knowledge enhancement, Knowledge delivery and Knowledge evaluation. These include e-learning, e-library, on-line examination, and evaluation and feedback systems as an integral part.

Information administration is considered as another vital part of e-administration. It is required to have continued focus on the contribution of higher education to the national and global economy. This aspect emphasizes the importance of performing educational administration of higher educations with effectiveness and efficiency. Various literature reviews reveal that information administration is one part of overall administration of education institutions which mainly covers general and day-to-day operational activities. Hence, it could be concluded that Information administration cycle includes four major components namely, Student administration, Staff administration, and General administration.

The evolution of higher education in India combined with the need to sustain and be competitive in a global scenario requires decisions to be taken quickly and effectively. This has enhanced the scope and complexity of administration, thus making it necessary to adopt different methods of higher education administration. In this regard, improved levels of deployment of e-administration in higher education institutions are being considered. A theoretical model has been formulated for e-administration.

\section{METHODOLOGY}

The items that contribute towards the two major functional areas namely Knowledge administration and Information administration were carefully identified through extensive literature review and discussions with educational practitioners and experts. A questionnaire was prepared and validated through the pilot study. The reliability and AVE were calculated. The relevant functional areas of e-administration were also profiled together with their mean and standard deviation scores. This was done to examine the average values and the variation. The relationships between the indicators for e-administration were examined. Correlation technique was used for analyzing the association between the indicators of e-administration. Pearson correlation test using SPSS was done to establish this. Finally path diagram constructed using visual PLS is estimated using bootstrapping technique and evaluated using the fit indices.

\section{ANALYSIS AND INFERENCES}

The overall mean score for the functional areas of e-administration was 3.55 which revealed that all the functional areas contribute well towards e-administration. It can be observed that knowledge delivery and evaluation has the highest mean value (Table 1.1), and general administration has the lowest mean value. Therefore the sample represents the highest importance assigned to knowledge delivery and evaluation than general administration in technology-based administration in higher education institutions. As revealed by various literature reviews, ICT plays a vital role in the teaching-learning process and the sample also indicates that the application of technology is more visible in knowledge delivery and evaluation than general administrative activities. Though general administration is an important element of e-administration, it is clear from the responses that it is not widely available in practice.

TABLE I. PROFILE OF FunCtionAl AREAS OF E-ADMINISTRATION

\begin{tabular}{|l|c|c|}
\hline \multicolumn{3}{|c|}{ Functional Areas of e-Administration } \\
\hline Functional Areas & $\begin{array}{c}\text { Mean } \\
\text { Statistic }\end{array}$ & $\begin{array}{c}\text { Std. } \\
\text { Deviation } \\
\text { Statistic }\end{array}$ \\
\hline Knowledge Acquisition and Enhancement & 3.92 & 0.758 \\
\hline Knowledge Delivery and Evaluation & 3.97 & 0.631 \\
\hline Knowledge Administration & 3.73 & 0.722 \\
\hline Student Administration & 3.52 & 0.756 \\
\hline Staff Administration & 3.30 & 0.732 \\
\hline General Administration & 2.82 & 0.531 \\
\hline Information Administration & 3.54 & 0.553 \\
\hline
\end{tabular}

Analysis was done to see whether the indicators for e-administration had a statistically significant relationship with each other. Pearson correlation test revealed that all the constructs correlate positively with each other at 0.01 or 0.05 level of significance. 
TABLE II. CORRELATION BETWEEN THE INDICATORS OF E-ADMINISTRATION

\begin{tabular}{|c|c|c|c|c|c|c|c|}
\hline \multicolumn{8}{|c|}{ Indicators of e-Administration } \\
\hline & kae & $k d$ & $k a$ & stu & stf & $g a$ & $i a$ \\
\hline kae & 1 & & & & & & \\
\hline $\mathrm{Kd}$ & $\begin{array}{c}0.717 \\
(* *)\end{array}$ & 1 & & & & & \\
\hline ka & $\begin{array}{c}0.623 \\
(* *)\end{array}$ & $\begin{array}{c}0.687 \\
(* *)\end{array}$ & 1 & & & & \\
\hline stu & $\begin{array}{c}0.272 \\
(*)\end{array}$ & $\begin{array}{c}0.228 \\
(*)\end{array}$ & $\begin{array}{c}0.332 \\
(* *)\end{array}$ & 1 & & & \\
\hline stf & $\begin{array}{c}0.340 \\
(* *)\end{array}$ & $\begin{array}{c}0.477 \\
(* *)\end{array}$ & $\begin{array}{c}0.478 \\
(* *)\end{array}$ & $\begin{array}{c}0.435 \\
(* *)\end{array}$ & 1 & & \\
\hline ga & 0.195 & $\begin{array}{c}0.266 \\
(*)\end{array}$ & $\begin{array}{c}0.276 \\
(*)\end{array}$ & $\begin{array}{c}0.591 \\
(* *)\end{array}$ & $\begin{array}{c}0.356 \\
(* *)\end{array}$ & 1 & \\
\hline ia & $\begin{array}{c}0.224 \\
(*)\end{array}$ & $\begin{array}{c}0.311 \\
(* *)\end{array}$ & $\begin{array}{c}0.286 \\
(*)\end{array}$ & $\begin{array}{c}0.300 \\
(* *)\end{array}$ & $\begin{array}{c}0.320 \\
(* *)\end{array}$ & $\begin{array}{c}0.301 \\
(* *)\end{array}$ & 1 \\
\hline
\end{tabular}

The items contributing to knowledge acquisition / enhancement and knowledge delivery were grouped to find the extent to which technology is currently in use. This was done to identify the extent of usage of technology for overall knowledge administration construct $(\mathrm{ka})$. It was inferred from the analysis that $73.3 \%$ of the respondents utilized technology for Knowledge acquisition and enhancement, and $75.7 \%$ for Knowledge delivery. The analysis revealed that the current technology utilization is $65.1 \%$ for overall knowledge administration and $58.5 \%$ for Information administration.

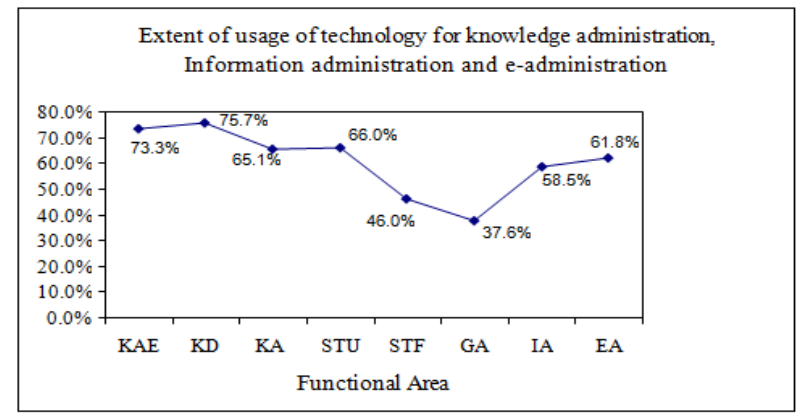

Figure 1. Extent of usage of technology for knowledge administration, information administration and e-administration

\section{FINDINGS}

- The demographic factors were profiled and their impact on e-administration was studied. It was found that demographic factors do not have a major impact on e-administration in higher education institutions.

- The extent to which technology is being currently used in the various functional areas of e-administration in higher education institutions was analyzed. The usage of technology for Knowledge administration activities was found to be higher than that of Information administration activities
- The functional areas of e-administration and the items constituting them were ranked on the basis of utilization of technology. This revealed that technology was used to the maximum extent in the area of Knowledge delivery and evaluation which is an important indicator for the functional area of knowledge administration.

- Though General administration is an important functional area of Information administration, the utilization of technology was found to be the least among all the functional areas.

- Among the items related to the functional areas of knowledge administration, the highest usage of technology was for Internet browsing by faculty members to supplement book information and the least usage was for the conduct of online tests / online quizzes

- The highest usage of technology in the area of Information administration was found in the area of admission processes through electronic media and the least usage was regarding electronic mode of payment of fees by students.

- All the identified functional areas were found to have an impact on overall e-administration in higher education institutions

- A model relating the various functional areas of knowledge administration and information administration leading to e-administration was estimated and found fit as shown in figure- 2 below.

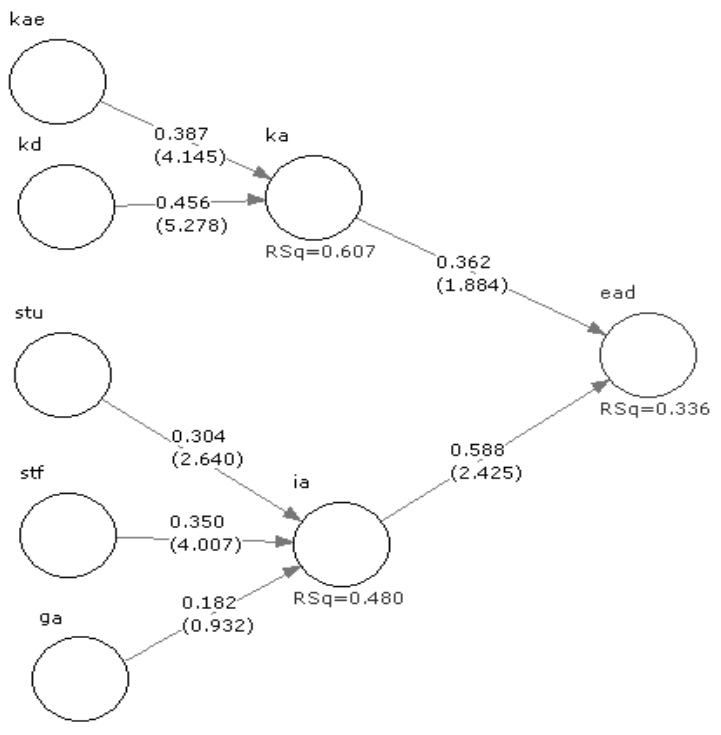

VI. CONCLUSION

This study has identified a comprehensive set of functional areas of e-administration. This study revealed that demographic factors do not have a major impact on e-administration in higher education institutions. It is also evident from this study that integration of ICT into knowledge administration for the teaching-learning process is more in comparison with 
information administration. Hence, enhancing the usage of ICT on to these functional areas will improve the overall e-administration. This study could serve as a base for education planners and academicians to deploy ICT-based administration in higher education to enhance overall quality of the system.

\section{REFERENCES}

[1] Balasubramaniam, Background paper from the Commonwealth of Learning for the UNESCO World Conference on Higher Education. Paris, July 6 to 8, 2009.

[2] Ben-Zion Barta, "Information Technology in Educational Management", Chapman and Hall, London, 1995.

[3] Chirstiana Maki, "Information and Communication Technology for Administration and Management for secondary schools in Cyprus", Journal of Online Learning and Teaching Vol. 4 No. 3, 2008.

[4] Diem Ho,"Research, Innovation and Knowledge Management: the ICT Factor", Submitted to UNESCO, July 20, 2007.

[5] Harsh.V. Pant, "Crisis in higher education Universities are in the news more for politics than for research", The Tribune special on-line edition 2009 (http://www.tribuneindia.com).

[6] Maynard J. Bratlien, "Computer Development in Educational Administration", the Journal (Technological Horizons in Education), Vol. 16, 1989.

[7] The Department of Education, Ministry of Human Resource Development, Government of India. Report 2009-2010 (http://www.education.nic.in)

[8] UNESCO World Conference on Higher Education for the Twenty-First Century: Vision and Action, Commission II: Quality of Higher Education, Final Report, Paris: UNESCO, pp.34., 1998.
[9] Sanat Kaul, "Higher Education in India: Seizing the Opportunity", (ICIER Working Paper No. 179), New Delhi: Indian Council for Research on International Economic Relations May 2006. (http://www.icrier.org)

\section{AUTHORS PROFILE}

\section{J. Meenakumari}

Meenakumari has submitted her doctoral thesis in the integrated topic of Management and IT. She has completed her post graduation and M. Phil in Computer science with distinction. She has fifteen years of teaching experience which includes corporate training and teaching in post graduate courses. Her experience also includes a stint with the Tata group as a center in-charge related to academics and conduct of examinations.

She has been a Keynote speaker and Session chair for the International Conference ICETC 2009 organized by IEEE and IACSIT held at Singapore and also in various international and national conferences and seminars. She has presented papers in various international and national conferences. She won two best paper awards in two international conferences. She has authored research articles in refereed international and national journals. She is a committee member of International Association of Computer Science and Information Technology (IACSIT) and a life member of ISTE. She is also a reviewer for reputed international journals.

\section{Dr. R. Krishnaveni}

Dr. R. Krishnaveni is presently Professor in PSGIM, PSG College of Technology, Coimbatore, Tamilnadu. She has twenty five years of teaching and research experience. Her publications include 4 books and 60 research articles in international and national journals. She has been instrumental in organizing National level conferences as well as workshops annually in the area of Business Research. Her popular book includes "Human Resource Development - a Researcher's Perspective" (2008). She is the executive editor of the journal titled "Journal of contemporary research in management ". 